\title{
The influence of clinical experience and gender in the manual application of torque on screws of implant-supported prosthesis
}

\author{
A influência da experiência clínica e do gênero na aplicação manual \\ de torque em parafusos de prótese suportada por implante
} La influencia de la experiencia clínica y el género en la aplicación manual
de torque en tornillos de prótesis sobre implantes

Ebele Adaobi SILVA ${ }^{1}$

Cecília Alves de SOUSA ${ }^{2}$

Maria Cristina Rosifini ALVES REZENDE ${ }^{2}$

Paulo Henrique dos SANTOS ${ }^{2}$

Wirley Gonçalves ASSUNÇÃO ${ }^{2}$

\author{
${ }^{1}$ Department of Dental Materials and Prosthesis, University of São Paulo (USP), \\ School of Dentistry, Ribeirão Preto, São Paulo, Brazil \\ ${ }^{2}$ Department of Dental Materials and Prosthesis, São Paulo State University (UNESP), \\ School of Dentistry, Araçatuba, São Paulo, Brazil
}

\begin{abstract}
Compare with the torque value recommended by the manufacturer, the values of maximum closing torques generated by volunteers of the male and female gender, with and without experience in implant-prosthesis, for tightening the screw UCLA abutment retention. The hypotheses tested were that the greatest experience in the field would not influence the value of the applied torque, as there would be no difference between volunteers from different genders. In this way, 266 volunteers were classified according to their expertise in pre-clinical (PC), clinical (C) and professional (P). Were placed seated, simulating normal forward work position in front a digital torque meter. A specimen composed of an external hex implant embedded in modified polyester resin, a metal crown and its retaining screw was attached on torque meter. The participants were provided with directions to tighten the abutment retaining screw by using a manual torque driver and apply full force in one movement of rotation. The professional group achieved the highest mean manual torque $(15.80 \mathrm{~N} / \mathrm{cm})$; males $(14.96 \mathrm{~N} / \mathrm{cm}) \mathrm{scores}$ a higher than females $(02.11 \mathrm{~N} / \mathrm{cm})$. They could not reach the torque value recommended by the manufacturer. Thus, the factors that influence the manual application of torque include the level of clinical experience and the physical strength of the operator. The conclusion is that the use of a calibrated mechanical driver torque is essential to apply a suitable and controlled torque value and capable of promoting a proper preload and maintaining the screwed joint for long periods.

Descriptors: Dental Implants; Dental Prosthesis, Implant-Supported; Stress, Mechanical.
\end{abstract}

\section{Resumo}

Comparar com o valor de torque recomendado pelo fabricante, os valores dos binários máximos de fechamento gerados por voluntários do gênero masculino e feminino, com e sem experiência em implante/prótese, para apertar a retenção de pilar UCLA de parafuso. As hipóteses testadas foram que a maior experiência no campo não influenciaria o valor do torque aplicado, pois não haveria diferença entre voluntários de diferentes gêneros. Desta forma, 266 voluntários foram classificados de acordo com sua experiência em pré-clínica (PC), clínica (C) e profissional (P). Foram colocados sentados, simulando a posição normal de trabalho na frente de um medidor de torque digital. Um espécime composto por um implante hexadecimal externo incorporado em resina de poliéster modificado, uma coroa de metal e seu parafuso de retenção foi preso no medidor de torque. Os participantes receberam instruções para apertar o parafuso de retenção do pilar usando um excitador de torque manual e aplicar força total em um movimento de rotação. $\mathrm{O}$ grupo profissional alcançou o torque manual médio mais alto $(15.80 \mathrm{~N} / \mathrm{cm})$; Os machos $(14,96 \mathrm{~N} / \mathrm{cm})$ obtêm pontuação superior às do sexo feminino $(02.11 \mathrm{~N} / \mathrm{cm})$. Eles não conseguiram alcançar o valor de torque recomendado pelo fabricante. Assim, os fatores que influenciam a aplicação manual do torque incluem o nível de experiência clínica e a força física do operador. A conclusão é que o uso de um torque de driver mecânico calibrado é essencial para aplicar um valor de torque adequado e controlado e capaz de promover uma pré-carga adequada e manter a junta parafusada por longos períodos.

Descritores: Prótese Dentária; Prótese Dentária Fixada por Implante; Estresse Mecânico.

\section{Resumen}

Comparar con el valor de torsión recomendado por el fabricante, los valores de los pares máximos de cierre generados por voluntarios del género masculino y femenino, con y sin experiencia en implante-prótesis, para ajustar la retención del pilar UCLA con tornillo. La hipótesis probada fue que la mayor experiencia en el campo no influiría en el valor del torque aplicado, ya que no habría diferencias entre los voluntarios de diferentes géneros. De esta forma, 266 voluntarios se clasificaron de acuerdo con su experiencia en preclínicos (PC), clínicos (C) y profesionales (P). Se colocaron sentados, simulando la posición de trabajo hacia delante normal en frente de un medidor de par digital. Una muestra compuesta de un implante hexagonal externo incrustado en resina de poliéster modificada, una corona de metal y su tornillo de retención se adjuntaron en el medidor de par. A los participantes se les proporcionaron instrucciones para apretar el tornillo de retención del pilar utilizando un destornillador de torque manual y aplicar toda la fuerza en un solo movimiento de rotación. El grupo profesional logró el torque manual medio más alto $(15.80 \mathrm{~N} / \mathrm{cm})$; los machos $(14,96 \mathrm{~N} / \mathrm{cm})$ puntúan más que las hembras $(02,11 \mathrm{~N} / \mathrm{cm})$. No pudieron alcanzar el valor de par recomendado por el fabricante. Por lo tanto, los factores que influyen en la aplicación manual del torque incluyen el nivel de experiencia clínica y la fortaleza física del operador. La conclusión es que el uso de un par motor mecánico calibrado es esencial para aplicar un valor de torque adecuado y controlado y capaz de promover una precarga adecuada y mantener la unión atornillada por largos períodos.

Descriptores: Prótesis Dental; Prótesis Dental de Soporte Implantado; Estrés Mecánico.

\section{INTRODUCTION}

The most common failure of implant-prostheses and restorations, loose retaining screws ${ }^{1-5}$, is mainly caused by applications of improper torque ${ }^{6-12}$. Other causes of loose retaining screws include fatigue, excessive bending and micro movements ${ }^{2}$. When insufficient torque is applied, the preload compressive clamping force that keeps together the 
components, decreases beyond a critical level. This allows external forces to cause sliding and vibrations of the screw threads which jeopardizes the stability of the bond and lead to unscrewing ${ }^{13,14}$.

It is difficult to eliminate the separation action that is generated since the prosthesis is subjected to multidirectional impact forces, such as those that occur during masticatory cycles. The only way to prevent loosening is to ensure that the forces required to separate them ${ }^{13}$.Therefore, the development of a proper preload is vital to preventing short-and long-term failure of the implant system/prostheses ${ }^{15}$. The greater the contact surface area between the abutment and the implant, the better the screw can tolerate external loads ${ }^{16}$. Thus, the higher the preload, the more is the resistance to loosening and stability of the screwed union ${ }^{17,18}$.

To prevent the loss of preload and reduce the potential for loosening of the retaining screw, the dentist must apply an appropriate amount of closing torque. Specific closing torques, ranging from 10 to $35 \mathrm{~N} / \mathrm{cm}$, are recommended for specific screws and depend on the type of implant systems, as well as, abutment screw design, diameter, material, and manufacturer ${ }^{6,19,20}$.

However, there is great variation in the ability of the professionals to discern whether they have applied the proper torque to the implant components ${ }^{21}$. One study, reported the results of a comparison of the manufactures' recommended closing torque values with the usual torque and closing maximum torque generated by experienced operators who used manual torque drivers during the placement of the abutment under simulated clinical conditions. The data showed that the usual closing torque of the operator was equal to or less than $50 \%$ the recommended maximum torque and the manual closing mean was less than $75 \%$ of the recommended torque values. Most believed that by applying a maximum clamping force, the torque recommended by manufacturers can be exceeded and promote damage at the bone-implant connection ${ }^{22}$. The aim of this study was to determine if the amount of torque generated manually by using a manual torque driver met the recommendations of the abutment screw manufacturers. It was measured the amount of maximum closing torque generated by experienced and inexperienced operators while using a manual torque driver to tighten the retaining screw a metal crown. This value was compared to the torque value recommended by the manufacturer to determine if the torque generated manually provided enough preload to maintain the stability of the screw union, thus lowering the incidence of screw loosening. Two test hypotheses were formulated; the first being that the most experience in the field would not influence the value of the applied torque, as there would be no difference in that respect between volunteers from different genders.

\section{MATHERIAL AND METHOD}

This research was approved by the Research Ethics Committee through the presentation of Certificate for Ethics Assessment No. 47897515.1.0000.5420 in 11/16/2015.

Two hundred and sixty-six volunteers participated in the study. After approval by ethics committee, we divided the volunteers into 3 groups according to their clinical experience with implant-supported prostheses: (1) preclinical stage (PC)- undergraduate dentistry students without prior clinical contact, (2) clinical stage (C) - dental students with prior clinical contact, but with only theoretical experience, (3) professional (P) - clinically experienced with varying degrees of clinical experience. The groups also subdivided according to gender (Table 1), female (FPC) and male (MPC) students in the pre-clinical stage, female (FC) and male (MC) students in the clinical phase, female (FP) and male (MP) professionals.

Table 1. Formation of groups: level of experience and gender of the participants

\begin{tabular}{ccc}
\hline & \multicolumn{2}{c}{ Gender } \\
\cline { 2 - 3 } Level of experience & Female & Male \\
\hline Pre-clinical (PC) & 64 & 24 \\
\hline Clinical (C) & 69 & 33 \\
\hline Professional (P) & 32 & 44 \\
\hline Total & 165 & 101 \\
\hline
\end{tabular}

All volunteers were asked to tighten retaining screw (DSP Biomedical ${ }^{\circledR}$, Campo Largo, Paraná, Brazil) of the metal crown on an external hexagon implant $(4 \mathrm{x} 13 \mathrm{~mm})$ (DSP Biomedical ${ }^{\circledR}$, Campo Largo, Paraná, Brazil) that was embedded in modified polyester resin (Technovit 4000Heraeus Kilzer, Wehrheim, Germany).

They were seated, in a position that simulated their normal working positions, while in front of a digital torque meter (Torque Tool Tester, TST series 2 Norbar ${ }^{\circledR}$, Navi, Mumbai, India) that was coupled the specimen, and were given a long digital key $24 \mathrm{~mm}$ (SIN - System implant, São Paulo - SP, Brazil) as the handheld-device of torque. Subsequently, we instructed them to use the manual torque driver to tighten the screw and apply maximum bi-digital force in one movement of rotation. Under supervision, they performed this procedure three times, with an interval of 3 minutes between each squeeze. The values recorded in the torque meter were registered. Individual and group means of the manual torque applied were calculated.

Data were analyzed using the Statical software R (Free Software Foundation, Viena, Áustria) with a 0.05 level of statistical significance. Since the torque values were not normally distributed $(\mathrm{p}<0.05)$, used the nonparametric Shapiro-Wilk-test.

\section{RESULTS}

The overall mean torque obtained manually was $12.51 \mathrm{~N} / \mathrm{cm}$, which is $41.7 \%$ of the torque values recommended by the manufacturer. Table 2 presents the means and standard deviations of the manual torque according to gender. Men had a statistically significant ( $\mathrm{p}<0.05)$ higher mean $(14.96 \mathrm{~N} / \mathrm{cm})$ than women $(11.02 \mathrm{~N} / \mathrm{cm})$.

Table 2. Manual torque values $(\mathrm{N} / \mathrm{cm})$ for the ender of participants, regardless of level of experience

\begin{tabular}{cc}
\hline Gender & Mean \\
\hline Female & $11.02 \pm 3.87^{\mathrm{a}}$ \\
\hline Male & $14.96 \pm 4.68^{\mathrm{b}}$ \\
\hline
\end{tabular}

As shown in Table 3, comparing the torque values by experience level, the highest value was found in $\mathrm{P}(15.80$ $\mathrm{N} / \mathrm{cm})$ and the lowest in $\mathrm{PC}(9.89 \mathrm{~N} / \mathrm{cm})$. It found no statistically significant difference between the three levels of experience ( $\mathrm{PC}, \mathrm{C}$ and $\mathrm{P}$ ). In multiple comparisons between the levels of experience. There was no statistically significant difference among all groups (PC and $\mathrm{C}, \mathrm{Pc}$ and $\mathrm{P}, \mathrm{C}$ and $\mathrm{P})$.

Table 3. Mean and standard deviation of manual torque values $(\mathrm{N} / \mathrm{cm})$ for the level of experience of participants, regardless of gender

\begin{tabular}{cc}
\hline Level of experience & Mean \\
\hline Pre-clinical (PC) & $9.89 \pm 3.36^{\mathrm{a}}$ \\
\hline Clinical (C) & $12.34 \pm 3.74^{\mathrm{b}}$ \\
\hline Professional (P) & $15.80 \pm 4.89^{\mathrm{c}}$ \\
\hline
\end{tabular}


Table 4 presents the means and standard deviations of the manual torque according to gender and level of experience. The FPC group generated the lowest amount of torque $($ mean $=9.18 \mathrm{~N} / \mathrm{cm})$, while the MP group generated the greatest amount of torque $($ men $=17.05 \mathrm{~N} / \mathrm{cm})$. There was a significant differences existed between the groups FPC x FC; FPC x MC; FPC x FP; FPC x MP; MPC x MP; $\mathrm{FC} \times \mathrm{MC} ; \mathrm{FC} \times \mathrm{MC}$.

Table 4. Mean and standard deviation of manual torque values $(\mathrm{N} / \mathrm{cm})$ for the level of experience and gender of participants

\begin{tabular}{ccc}
\hline Level of experience & \multicolumn{2}{c}{ Gender } \\
\cline { 2 - 3 } & Female & Male \\
\hline Pre-clinical (PC) & $9.18 \pm 3.31^{\mathrm{Aa}}$ & $11.78 \pm 2.73^{\mathrm{Aa}}$ \\
\hline Clinical (C) & $11.30 \pm 3.16^{\mathrm{Ab}}$ & $14.48 \pm 3.99^{\mathrm{Bab}}$ \\
\hline Professional (P) & $14.07 \pm 4.27^{\mathrm{Ab}}$ & $17.05 \pm 4.97^{\mathrm{Ab}}$ \\
\hline
\end{tabular}

The mean amount of torque generated manually by each group, ranging between $30.60 \mathrm{~N} / \mathrm{cm}$ and $56.83 \%$ of the recommended torque, (Table 5) was significantly lower than that recommended by the manufacturer $(30 \mathrm{~N} / \mathrm{cm})$.

Table 5. Means of comparison the manual torque values between the value recommended by the manufacturer $(\mathrm{N} / \mathrm{cm})$

\begin{tabular}{ccccc}
\hline Groups & Recommended & $\begin{array}{c}\text { Mean } \\
\text { (N/cm) }\end{array}$ & $\begin{array}{c}\text { Variation for } \\
\text { the } \\
\text { recommended } \\
\text { value }\end{array}$ & $\begin{array}{c}\text { Coefficient } \\
\text { of variation } \\
(\%)\end{array}$ \\
\hline FPC & 30 & $9.18^{*}$ & $30.60 \%$ & 36.08 \\
\hline FC & 30 & $11.30^{*}$ & $37.66 \%$ & 27.99 \\
\hline FP & 30 & $14.07^{*}$ & $46.90 \%$ & 30.41 \\
\hline MPC & 30 & $11.78^{*}$ & $39.26 \%$ & 23.22 \\
\hline MC & 30 & $14.48^{*}$ & $48.26 \%$ & 27.55 \\
\hline MP & 30 & $17.05^{*}$ & $56.83 \%$ & 29.18 \\
\hline
\end{tabular}

\section{DISCUSSION}

The two test hypotheses were rejected, since both clinical experience how gender influenced the torque values. By including volunteers of different experience levels, analyzed the amount of torque applied to an implantsupported prostheses when using a manual torque driver under experimental conditions that simulates the clinical working position. In summary, the data showed that the mean maximum manual closure torque achieved by any group was less than the value recommended by the manufacturer $(30 \mathrm{~N} / \mathrm{cm})$. The male participants had a significantly higher mean than the female participants.

This data suggests that clinical experience influences the amount of torque generated manually. When it was compared torque only by level of experience, the group of professionals $(\mathrm{P})$ were able to achieve higher torque values. However, only two men, of the 76 total participants in the $\mathrm{P}$ group generated the recommended amount of torque. The group of students who did not have clinical experience (PC) generated the lowest mean torque, which was less than one third of the manufacturer recommended torque. It was also noted that most subjects in PC group were not familiar with the components of the screwed joint and manual applicator torque, reinforcing the notion that clinical experience may influence the application of torque. This is also supported by comparison of experience levels by gender.

The FPC and MPC had the lowest mean torque, while the professional groups (FP and MP) had the highest mean. When comparing only the female participants there was no significant difference seen in the groups according to clinical experience FC and FP. However, the female participants in the pre-clinical stage (FPC), who had the lowest mean of whole study, were statistically different from the other female groups. When comparing the male participants, there was a diffenrence between the pre-clinical groups (MPC) and professional (MP), who achieved the lowest and highest mean torque, respectively, while the values from the MC group did not differ statistically from the other two.

When comparing according to gender, the preclinical stage groups (FPC x MPC) and professionals (FP x MP), did not differ significantly. However, there was a significant difference between the FC and MC groups. The MC group achieved the highest mean. In addition, the FPC group showed a statistically significant difference from the MC and MP groups. The MPC group showed no statistically significant difference when compared the FC and FP groups. These data support the notion that male physical strength produces higher torque values, despite having less clinical experience than the females. This reinforces the need to use mechanical torque drivers to achieve the recommended torque values, regardless of the gender of the participants.

When comparing the values obtained in this study with the value recommended by the manufacturer, no group reached a level of torque that was close to ideal. To evaluate the distribution of torque values within each group, was calculated the coefficient of variation and expressed it as a percentage. A lower percentage indicates a more homogeneous group. The most homogeneous group was the MPC, while the most heterogeneous group was the FPC group had the widest distribution of values (mean torque ranged between 3.77 and $18.39 \mathrm{~N} / \mathrm{cm}$ ), while the other groups showed less variation.

This study simulates conditions in which volunteers did not have to deal with saliva and restricted or poor visibility. These conditions can make it more difficult to perceive and apply proper torque using manual torque driver in real clinical conditions.

Knowing that few minutes after the application of torque there is a loss of preload and the masticatory load tends to further decrease this preload and even promotes screw loosening and fracture of the retaining screw ${ }^{16,20,23-29}$. [16,20,23-29] This study reaffirms the need to use a calibrated mechanical torque drivers to apply torque to screws of the abutments ${ }^{21}$, for using the manual torque driver (bidigital key), even if using the maximum force, are not achieved values torque appropriate to produce the ideal preload in screws which require greater than $20 \mathrm{~N} / \mathrm{cm}$. Which compromises the maintenance union of these screwed joint for long periods.

\section{CONCLUSION}

Respecting the limitations of the study, we can conclude that the increased knowledge and clinical experience are important to achieve higher torque values when using bidigital manual torque driver, but not the only determinant, since the physical strength, presumed higher in males showed significantly influence the results obtained.

\section{ACKNOWLEDGMENTS}

The authors are grateful to teacher Paulo Henrique dos Santos and Taciana Kisaki Oliveira Shimizu by statistical analysis $(\mathrm{PhD}$ student in the course of the Graduate Inter-Institutional Program in Statistics from the University of São Paulo (USP) and Federal University of São Carlos (UFSCar) and the volunteers of this study.

\section{REFERENCES}

1. Sahin C, Ayyildiz S. Correlation between microleakage and screw loosening at implant-abutment connection. J 
Adv Prosthodont. 2014; 6(1):35-8.

2. Laney WR, Jemt T, Harris D, Henry PJ, Krogh PH, Polizzi $G$ et al. Osseointegrated implants for singletooth replacement: progress report from a multicenter prospective study after 3 years. Int J Oral Maxillofac Implants. 1994; 9(1):49-54.

3. Jemt T, Pettersson P. A 3-year follow-up study on single implant treatment. J Dent. 1993; 21(4):203-8.

4. Carlson B, Carlsson GE. Prosthodontic complications in osseointegrated dental implant treatment. Int J Oral Maxillofac Implants. 1994; 9(1):90-4.

5. Kim ES, Shin SY. Influence of the implant abutment types and the dynamic loading on initial screw loosening. J Adv Prosthodont. 2013; 5(1):21-8.

6. Jorneus L, Jemt T, Carlsson L. Loads and designs of screw joints for single crowns supported by osseointegrated implants. Int $\mathbf{J}$ Oral Maxillofac Implants. 1992; 7(3):353-9.

7. Martin WC, Woody RD, Miller BH, Miller AW. Implant abutment screw rotations and preloads for four different screw materials and surfaces. J Prosthet Dent. 2001; 86(1):24-32.

8. Drago CJ. A clinical study of the efficacy of gold-tite square abutment screws in cement-retained implant restorations. Int J Oral Maxillofac Implants. 2003; 18(2):273-8.

9. Renton T, Hankins M, Sproate C, McGurk M. A randomised controlled clinical trial to compare the incidence of injury to the inferior alveolar nerve as a result of coronectomy and removal of mandibular third molars. Br J Oral Maxillofac Surgery; 2005; 43(1):7-12.

10. Siamos G, Winkler S, Boberick KG. Relationship between implant preload and screw loosening on implant-supported prostheses. J Oral Implantol. 2002; 28(2):67-73

11. Schwarz MS. Mechanical complications of dental implants. Clin Oral Implants Res. 2000; 11(Suppl 1):156-8.

12. Satterthwaite J, Rickman L. Retrieval of a fractured abutment screw thread from an implant: a case report. Br Dent J. 2008; 204(4):177-80.

13. McGlumphy EA, Mendel DA, Holloway JA. Implant screw mechanics. Dent Clin North Am. 1998; 42(1):71-89.

14. Michalakis K, Calvani PL, Muftu S, Pissiotis A, Hirayama $\mathrm{H}$. The effect of different implant-abutment connections on screw joint stability. J Oral Implantol. 2014; 40(2):146-52.

15. Cho SC, Small PN, Elian N, Tarnow D. Screw loosening for standard and wide diameter implants in partially edentulous cases: 3- to 7-year longitudinal data. Implant Dent. 2004; 13(3):245-50.

16. Kano SC, Binon P, Bonfante G, Curtis DA. Effect of casting procedures on screw loosening in UCLA-type abutments. J Prosthodont. 2006; 15(2):77-81.

17. Jaarda MJ, Razzoog ME, Gratton DG. Effect of preload torque on the ultimate tensile strength of implant prosthetic retaining screws. Implant Dent. 1994; 3(1):17-21.

18. Sakaguchi RL, Borgersen SE. Nonlinear contact analysis of preload in dental implant screws. Int J Oral Maxillofac Implants. 1995; 10(3):295-302.

19. Naert I, Quirynen M, van Steenberghe D, Darius P. A study of 589 consecutive implants supporting complete fixed prostheses. Part II: Prosthetic aspects. J Prosthet Dent. 1992; 68(6):949-56.
20. Delben JA, Gomes EA, Barao VA, Assunção WG. Evaluation of the effect of retightening and mechanical cycling on preload maintenance of retention screws. Int J Oral Maxillofac Implants. 2011; 26(2):251-6.

21. Goheen KL, Vermilyea SG, Vossoughi J, Agar JR. Torque generated by handheld screwdrivers and mechanical torquing devices for osseointegrated implants. Int J Oral Maxillofac Implants. 1994; 9(2):149-55.

22. Gross M, Kozak D, Laufer BZ, Weiss EI. Manual closing torque in five implant abutment systems: an in vitro comparative study. J Prosthet Dent. 1999; 81(5):574-8.

23. Pjetursson BE, Bragger U, Lang NP, Zwahlen M. Comparison of survival and complication rates of toothsupported fixed dental prostheses (FDPs) and implantsupported FDPs and single crowns (SCs). Clin Oral Implants Res. 2007; 18(Suppl 3):97-113.

24. Wittneben JG, Buser D, Salvi GE, Bürgin W, Hicklin S, Brägger U. Complication and failure rates with implantsupported fixed dental prostheses and single crowns: a 10-year retrospective study. Clin Implant Dent Relat Res. 2014; 16(3):356-64.

25. Goodacre CJ, Kan JY, Rungcharassaeng K. Clinical complications of osseointegrated implants. J Prosthet Dent. 1999; 81(5):537-52.

26. Worthington P, Bolender CL, Taylor TD. The Swedish system of osseointegrated implants: problems and complications encountered during a 4-year trial period. Int J Oral Maxillofac Implants. 1987; 2(2):77-84.

27. Zarb GA, Schmitt A. The longitudinal clinical effectiveness of osseointegrated dental implants: the Toronto study. Part III: Problems and complications encountered. J Prosthet Dent. 1990; 64(2):185-94.

28. Assunção WG, Barao VA, Delben JA, Gomes EA, Garcia IR Jr. Effect of unilateral misfit on preload of retention screws of implant-supported prostheses submitted to mechanical cycling. J Prosthodont Res. 2011; 55(1):12-8.

29. Assunção WG, dos Santos PH, Delben JA, Gomes EA, Barão VA, Tabata LF. Effect of misfit on preload maintenance of retention screws of implant-supported prostheses. J Mater Eng Perform. 2009; 18(7):935-8.

\section{CONFLICTS OF INTERESTS}

The authors declare no conflicts of interests.

\section{CORRESPONDING AUTHOR}

\section{Cecília Alves de Sousa}

ceciliasousa_alves@hotmail.com

Received 14/11/2017 Accepted 09/01/2018 